\title{
Tackling Multiculturalism or Strengthening Subcultures: the Macedonian Case
}

\author{
Aleksandar Dashtevski PhD
}

Ass. Prof., UTMS- Skopje, Macedonia

Gorjan Grncharovski

UTMS- Skopje, Macedonia

\begin{abstract}
There is no general formula about what multiculturalism means exactly, and which rights it should encompass. It needs to be considered from various aspects. In the case of Macedonia, there are several ethnic groups in it that are in the vicinity of their home countries, which seek to protect their nationals from repression and discrimination. However, Albania is the most aggressive one and, in spite of direct contacts with Macedonian politicians from the Albanian ethnic group, it often interferes with the internal affairs of the Macedonian state. Although in Macedonia all collective rights are given to the ethnic minorities, including much more than what constitutes an international standard in Europe and in the world, in accordance with the Ohrid Framework Agreement of 2001, implemented in the state's constitution, relations do not seem to be improving. On the contrary, other rights are constantly being sought, even higher than those set for the majority population in the country. On the other hand, the establishment of increased rights in the constitution and laws does not lead to coexistence and relaxation of the relations between the Macedonian and the Albanian communities. On the contrary, the Albanians are becoming ghettoized and live in separate communities, where they create their own subculture. Such behavior leads to greater segregation, which can create cantonization or federalization of the unitary state.
\end{abstract}

Keywords: tackling, multiculturalism, strengthening, subcultures, Macedonia.

\section{Introduction}

Nowadays, there is almost no country in the world that is not multicultural. That makes the issue very current and relevant, especially in the Western world, which is a generator of resolving all issues related to certain human rights and freedoms. Over the centuries, people have found solutions within a particular territory and a community, as if respecting each other's values. It was based mainly on tradition and customs. In the present time, it becomes a more fragmented question. Every day, things are changing, and the solutions are not very precisely defined and different, it depends on which part of the world is happening. More recently, issues about different ethnic groups are resolved using documents of various characteristics such as international, bilateral or internal.

There have also been different scientific themes that offer solutions to minority issues. Almost all of these theories agree that it is very difficult to solve the problems of multiculturalism. In particular, when it should be regulated by an international document. Often such documents only regulate certain areas. In 1992, the Council of Europe adopted a Declaration on the Rights of Minority Languages and then several other documents in that direction.

Macedonians and Albanians have been living together for centuries in the Balkans, but the problems between them begin after the end of World War II. Given that Albania strengthens its state, they become a minority, especially within the former Yugoslavia. The situation is getting worse, after gaining full independence in 1991, new requests by the minority are continually being made, and the story never ends.

\section{Multiculturalism - a never ending story}

The problem that usually arises when we talk about multiculturalism is in what way should be resolved such an issue. Is it to be resolved with the international standards for individual human rights, which apply equally to all, or it is necessary to determine special collective rights for other communities in that society. It seems that in the last 20 years the opinion 
prevails that it is necessary that these rights ought to be regulated in a collective way. But that is not the only problem here. What is more problematic is that, whatever to do in that direction, new problems might appear. Therefore, multiculturalism should be considered seriously, and on a case-by-case basis.

What would have to be a new perspective on cultural diversity and international order? International orders evolve in heterogeneous? International orders evolve in heterogeneous cultural contexts, and the governance of diversity is a key imperative of order building. In response, international orders develop diversity regimes: institutional norms and practices that define legitimate units of political authority, authorize certain forms of cultural difference and relate the two. These regimes are essential to the legitimacy of international orders but face two interrelated pressures for change: shifts in underlying material capabilities, and new claims for cultural recognition, often rooted in grievances against past or prevailing forms of recognition (Reus-Smith Christian 2017).

It is necessary to mention the influence of liberal capitalism which offers an alternative liberal response to the challenge of diversity. Political liberalism includes many different visions of a political morality considered fit for the purpose of regulating and legislating for diverse societies. There are, however, some shared and recurring elements. Thus, political liberalism rejects the attempt to found liberal political morality upon substantively normative, ostensibly liberal values and norms, such as personal autonomy and, in some cases, moral equality. Political liberalism acknowledges the existence of many cultural communities which would have to change fundamentally in order to comply with the values espoused by muscular liberalism. Political liberals typically argue that it is unreasonable for the state to demand compliance with substantively liberal values and norms from all who are subject to the state's jurisdiction. In some cases, pejoratively comparing the practices and beliefs of some non- or illiberal communities with those, often rather idealised, notions of muscular liberalism is deeply disrespectful of other ways of being and believing. The likely consequence of this, it is sometimes argued, is stoking the very fires of alienation and hostility which muscular liberalism is supposedly intended to prevent. Ultimately, political liberalism considers its muscular counterpart as incapable of establishing and maintaining peace and stability (Fagan, Andrew 2017).

Levante Salat (2001) has shown that the theoreticians of multiculturalism do not consider the common democratic mechanisms as sufficient to properly solve the problem of multicultural societies. Thus a new context is needed. The concept of collective rights lies in the centre of this model but not opposed to individual freedom, just as a prerequisite for it.

According to Charles Taylor, within the political life, one has sometimes stringently felt the need for recognition. The need lies behind the nationals movements and behind other forms of gaining the right to representation by what is regarded as "subordinate" groups. He argued that trough the identity, one can define the way in which a person understands himself and the defining fundamental features that a human being possesses. He stated that democracy is built to the idea of mutual recognition which has various shapes. Starting from the principles, multiculturalism demands equal status for the different cultures. The accomplishment and the definition of identity rely on forms of expression, largely speaking, and include all forms of communication and artistic manifestation.

The recognition of cultural diversity is necessary, which is a rightful need. The policies of recognition, impose not only the obligation of recognizing other cultures but also of analysing them more closely and getting to know them (Wolf, Susan 1994).

In multicultural societies, the coexistence of different forms of life means ensuring the citizen's opportunity of growing up in a world of the cultural inheritance of modifying and transforming it. It shows that in multicultural societies the constitutional framework can tolerate only non-fundamentalists forms of life because the coexistence of certain communities with equal rights needs mutual recognition: all people are recognised as members of an ethnic community, with different conceptions of what good represents. In a society, the citizen can no longer find the consensus upon values, but they can identify a consensus upon the procedures of constituting the legal framework. A restricted communication within the political environment the democratic procedures of solving problems, and the channelling of the political power within the constitutional framework will supply a solid basis for monitoring political power and will offer assurance that the administrative power is used for everyone. The universalism of legal principles is reflected in the consensus upon procedures, which can be framed in the political power by means of a forum of constitutional patriotism. The ethos of the state as a nation cannot enter into conflict with civil rights as long as legislature is oriented towards constitutional principles. 
The ethical substance of political integration which unites all citizens must remain neutral and it must respect the differences between the cultural and ethical communities within a nation (Habermas 1994).

One of the most pressing problems faced by liberal democracies is the politicization of ethical and cultural differences. Social minorities demand more public recognition of their distinct identities, as well as more freedom and opportunities for keeping and developing their specific cultural practices.it leads to the protection of individual rights and it might be enough in order to manage the problems of ethical and cultural minorities. It is now widely accepted that these common rights of the citizens are not enough. Curtain different group rights are needed and there is a tendency within liberal democracies to recognize such rights. There is a distinction between national states and multi-ethnic states. Modern states are described as a nation-state, but most of them are multinational. The nation is described in sociological regard close to the idea of people or culture. If the country of a nation is incorporated within a larger state it becomes a national minority.

National minorities would like to obtain, keep and enhance their political autonomy by means of secession or other forms of regional autonomy. Minorities mobilize their members by making an appeal to the idea of a nation. If national minorities see a difference as normal, the geographical and political condition will make it different to understand. They appreciate that the historic ideal of a fully sovereign state is increasingly out-dated in a globalised world. There is an increasing interest to explore certain forms of self-government or federalist formula (Kymlicka W., and Almagor 2000).

The multicultural practices were not equally applied everywhere. The acceptance of multicultural practices depends on factors such as desecration of ethnic relationship, human rights, border control, the diversity of the groups of immigrants, economic contributions. When those conditions are met, multiculturalism is seen as an unacceptable option. Curtain multicultural policies include criteria such as constitutional recognition, the adoption of multicultural curricula in schools, double citizenship support for the cultural activities of the minorities, education in the maternal language etc (Kymlicka 2012).

Multiculturalism which proclaims differences as identities in which ignores the connection of resemblance leads to atomization, to a ghetto society. This could be avoided with the term of pluralism, which focuses on the opening of the communities between different communities. The principle on which pluralism realise is one of many, while the principle of multiculturalism is more dismembered. Multiculturalism does not permit an open society. In opposite, the extent to which multiculturalism nowadays is aggressive, secessionist intolerant, is the extent to which the given multiculturalism is the negation its self of pluralism (Sartori, 2007).

These trends are present in the Republic of Macedonia, but due to the policy of the stronger, the interference of the neighbouring states in its internal affairs, with the support of the international community on which they have a greater influence, not only provides more than it represents an international standard for minorities but also causes serious damage to the state, up to the limits of its abolition.

It should be taken into account that when talking about multiculturalism, double standards are often applied. So, if small countries are concerned, they need to make bigger concessions.

\section{Macedonian Case- A Recent Background}

Macedonia is part of Balkan peninsula. A thousand years of possession of Byzantine commonwealth in conjunction with the almost five centuries of the Ottoman Empire created such a mixture of languages, cultures, histories and religions that neither the most objective distinction could create an ethnically compact state. (Rudomentof V. 2000).

Most nationalisms of the Balkans have a defensive nature, their intensity is a direct consequence of the problems of unconsolidated national states and crises of social identity. Such anxiety in the relation of the issue of identity explains, among other things, the only Balkan obsession with ethnogenesis. In the permanent wholes of national states and with different intensity, this is the dominant tone in which historiography in the Balkans is practised (Todorova, M. 2009).

The creation of the modern Republic of Macedonia is a result of the struggle of Macedonian people for national independence and statehood throughout centuries. The contemporary Macedonian state, created in the course of the Second World War, was an ultimate result of a continuing historical process of national awakening and maturation of the people's awareness and of a long-lasting struggle for their own state and national freedom carried on under exceptionally difficult and complex historical circumstances. The first one is the llinden Uprising of the Macedonian people against Ottoman Empire on St. Elia's Day, August 2nd, 1903 in Krushevo. Then the Krushevo Republic - the first republic in the 
Balkans and the first independent state of the Macedonian nation were established. The second occasion was the struggle of the Macedonian nation for national liberation during the Second World War (1941-1945). Then the Macedonian state was created for the second and ultimately successful time - through the documents adopted at the First Session of ASNOM - Anti Fascist Assembly for the People's Liberation of Macedonia. (Cvetkovski, C.).

On August 2, 1944, the Macedonian state was constituted, today's independent and sovereign Republic of Macedonia. The first session of ASNOM, in fact, represents the state constitution of the Macedonian people and nationalities in Macedonia. The results achieved by holding this meeting represent the most significant historical achievement of the Macedonian people in the struggle for their own national state. The adopted state-constitutional acts of the Assembly only confirm this, among them: The decision to constitute the Anti-Fascist assembly of the national liberation of Macedonia in the supreme, legislative and executive body of Macedonia, the proclamation of the Macedonian language for an official language in the Macedonian state, as well as the decision for adopting a Declaration on the basic right of citizens in a democratic Macedonia (Macedonian Academy of Sciences and Arts 2014).

In this way, the basic preconditions for coexistence with minorities are provided. The development of these relations continues in the period of socialism.

In that period, a new Constitution of the Socialist Republic of Macedonia was adopted on February 25, 1974. According to the preamble of the constitution, two Macedonian people, together with the nationalities of Macedonia, in the common People's Liberation a struggle with other Yugoslav peoples and nationalities, created the Socialist Republic of Macedonia as a national state of the Macedonian people and a state of Albanian and Turkish nationality in it, in which the historical aspirations of the Macedonian people for national freedom and state independence, of the nationalities for equality and of the working class and of all working people for a socialist society. ${ }^{1}$

According to the paragraph, three Macedonian people, on the basis of the right to self-determination, including the right to secession, voluntarily unite with the other peoples of Yugoslavia together with the nationalities with which they live in a socialist federal community of free and equal peoples and nationalities, realizing that only it can provide conditions for its own free and universal national, material, political and cultural development. ${ }^{2}$

At that time, it was considered that these constitutions lead the process of democratization in the state. These conditions, for Albanians living in Macedonia, represented the basis that they received all rights as well as the Macedonians, including the right to self-determination until the separation.

Finally, as the third phase of the completion of independence of the state, on September 8, 1991, a referendum was held for the sovereignty and independence of the Macedonian state. The referendum is positive say $95.09 \%$ of the outgoing citizens or $72.16 \%$ of the total number of citizens with voting right. On this occasion, September 8 was declared state holiday - Independence Day of the state.

After the referendum ended, with the decision of the Assembly, the new Constitution of the Republic of Macedonia was adopted on November 17, 1991. According to the preamble of this Constitution, Macedonia is constituted as a national state of the Macedonian people, which ensures full civic equality and permanent coexistence of the Macedonian people with Albanians, Turks, Vlachs, Roma and other nationalities living in the Republic of Macedonia, with the aim of: the Republic of Macedonia to be constituted as sovereign and independent and as a citizen and a democratic state; to establish and build the rule of law as a fundamental system of government; to guarantee human rights, civil liberties, national equality; to ensure peace and co-existence of the Macedonian people with the nationalities living in the Republic of Macedonia and to ensure social justice, economic well-being and the progress of personal and community life ${ }^{3}$

The ethnic Albanians largely boycotted the 1991 referendum on Macedonia's independence from the former Yugoslavia and the adoption of a new constitution. Ethnic Albanian members of the parliament refused to participate unless the country's Albanian community was recognised as a constituent people of the republic, equal in status to the ethnic

\footnotetext{
${ }^{1}$ Official Gazette of the Socialist Republic of Macedonia, feb.25 1974 in Skopje, A Decision on the proclamation of the Constitution of the Socialist Republic of Macedonia, no.03-487, paragraph 2.

$2 \mathrm{lbid}$, paragraph 3.

${ }^{3}$ Decision on proclamation of the Constitution of Republic of Macedonia, November 17, 1991 Macedonian Assembly, no. 08-4642/1, 17, in Skopje.
} 
Macedonians. In particular, ethnic Albanian leaders objected to the wording of the constitution's preamble. Ethnic Albanians interpreted this clause as implying a lower constitutional status for non-ethnic Macedonian citizens and argued that the international community had an obligation to support efforts to amend the constitution (ICG 1998).

The Albanians had a long desire to be recognized not as a minority group but as equal partners in any kind of institutional arrangement. That is why the "moderate" Albanian nationalists in Macedonia seek the creation of a "bi-national" state, which may mean that they do not endanger the territorial integrity. It was in the early nineties (Rudomentof, V. 2000).

Therefore, disputes for the Albanians were, the arguments in the constitution that stipulate the official language in the territory of the whole country to be the Macedonian language, the Macedonian Orthodox Church to be an official religion, and most of them are Muslims, furthermore, primary and secondary education is permitted native language, but does not provide an opportunity for higher education. ${ }^{1}$

Because of these and other circumstances, tensions between the Macedonians and Albanians, which were settled in the period of the former Yugoslavia, grew especially during the nineties.

\section{Macedonian case- Current background}

According to estimates from early May 1999, more than 200,000 Kosovo refugees fled to Macedonia, overwhelming the already wasted economy and state infrastructure, increasing at the same time the number of Albanians in this small country undermining the majority status of ethnic Macedonians in that way. The key to Macedonian stability is prosperity and the improvement of relations between ethnic Macedonians and Albanians. However, the reluctance among Albanians and ethnic Macedonians is rising, while the West demonstrates its unwillingness to tackle this problem - which can cause the next crisis in the Balkans (Rudomentof, V. 2000:365).

Unofficially, the conflict in the Republic of Macedonia begins with the attack on a police station in a village named Tearce located in northwestern part of the state on January 22, 2001, and military actions continue in the next few months.

In February 2001, ethnic Albanian rebels calling themselves soldiers of the National Liberation Army (NLA) fighting for greater political and economic rights took control over Tanusevci village near the Kosovo-Macedonia border. This aggression started a series of violent clashes in various spots between NLA and Macedonian security forces, which lasted for about seven months (Jerker L. 2003).

The Ohrid Framework Agreement, signed on 13 August 2001, ended Macedonia's armed conflict between Albanian rebels and Macedonian security forces. The Ohrid Framework Agreement of 2001, as it is officially called, does not read like a classic peace accord. While the cessation of hostilities, disarmament of the Albanian rebels and a general amnesty were among its key provisions, most of the agreement concerned increased rights for the Albanian minority rights that would require substantial changes in key state institutions. On November 16, 2001, the contents of the contract amendments IV to XVIII were brought into the Constitution. Those amendments implemented over the minimum standards at that time had already begun to establish. ${ }^{2}$

Amendment $V$ determines the official language. Under paragraph 1 it is said that an official language all over the Macedonian territory is the Macedonian language. But now paragraph 2 states that another language spoken by at least $20 \%$ of the population is also an official language as well as its alphabet. Under paragraph 3 it is said- personal documents of citizens who speak an official language other than Macedonian, are published in Macedonian language and its alphabet, and in that language and its alphabet in accordance with the law. This amendment also states that other language can be used in communication with public authorities and institutions. In addition, it can be used as an official language in accordance with the law. Other languages used by at least 20 per cent of citizens are used in local government

\footnotetext{
1 See: Constitution of the Republic of Macedonia: with the amendments I-XXXII, articles, 7, 19, 48, ISBN 978-608-215-013-0, Akademski pecat, Skopje.

2 See Official Gazette of the Republic of Macedonia no.91, Macedonian Assembly on its session held on 16.11.2001 has adopted a Decision on proclamation of the amendments IV-XVIII of the Constitution.
} 
There should be adequate and equitable representation of citizens belonging to all communities in the state government and other public institutions at all levels, as stipulated in Amendment VI of the Constitution.1

The changes, despite the Macedonian Orthodox Church, amendment VII listed Islamic Religious Community in Macedonia, the Catholic Church, the Evangelical Methodist Church, the Jewish community and other religious communities and religious groups too ${ }^{2}$

In VIII amendment all cultural values of the communities in Macedonia are guaranteed. Members of the community have the right to establish cultural, artistic and educational institutions, as well as scientific and other associations for the expression, fostering and development of their identity. Amendment IX says that the Republic guarantees the protection, promotion and enhancement of historical, artistic heritage of Macedonia and all communities in Macedonia and the treasures that make up, regardless of their legal status. ${ }^{3}$

This amendment completely resolves the issue of education, requiring members of other communities, in their educational institutions to learn the Macedonian language. ${ }^{4}$

Other constitutional amendments relate mainly to the so-called rule of Badinter, by which in the main state institutions can't be decided if there is not a fair representation of the community, or a majority of them are not present in deciding on important issues. ${ }^{5}$

The fourth amendment which represents part of the preamble of the Constitution enumerates the foundations for peace and coexistence and individuality despite the majority and minority groups. So, it says that all citizens of Republic of Macedonia, the Macedonian people, as well as citizens living within its borders who are part of the Albanian people, Turkish people, Vlach people, Serbian, Roma, Bosniak people and others according to the amendment prominent intention to establish and strengthen the rule of law, are guaranteed human rights and civil liberties, to ensure peace and coexistence, social justice, economic well-being and progress of the individual and the common life, through its representatives in Parliament, elected in free and democratic elections.

Thus the Republic of Macedonia became a country that provides most minority rights. The agreement has been carried out since his signing date and soon the implementation has to be completed, according to the constitutional amendments. In addition, many benefits have been gained, since the amendments have been converted into laws. During the implementation of the agreement, complaints were raised not only with the majority but also with other non-Albanian minorities. They believe that the community has more rights than the majority (for example, in employment and other areas), and other minorities consider themselves in a subordinate situation.

On the other hand, in past years, there were more misunderstandings and conflicts on an ethnic basis (tensions, protests, fighting, killing, destruction of buildings, etc.). It shows that the current situation is hard to be managed especially when it comes to armed conflicts and boycotting the legislation.

Finally, after the early elections in December 2016, ethnic Albanian parties in Macedonia made a platform on 01 January 2017, which was a condition for joining a coalition with any party or coalition of the Macedonian parties, the socalled Tirana Platform, because it was achieved through the mediation of Albanian Prime Minister Edi Rama. It was titled "A Joint Platform of the Albanian Parties." Among other things, the platform had several extremely provocative requirements, such as achieving full linguistic equality, the use of the Albanian language at all levels of government, and a guarantee of its application as a fundamental and constitutional right. Furthermore, the Constitution of the Republic of Macedonia should establish that "the Macedonian language and its Cyrillic alphabet and the Albanian language with its letter are official languages in the Republic of Macedonia". Opening the issue of a comprehensive debate on the flag, the anthem and the state coat of arms of the Republic of Macedonia for state symbols to reflect social multiethnicity and ethnic

\footnotetext{
${ }_{1}$ Also, Official Gazette of the Republic of Macedonia no.91, date: 20.11.2001 година, Amendment VI, paragraph I.

${ }^{2}$ Official Gazette of the Republic of Macedonia no.91, date: 20.11.2001, Amendment VIII, paragraph 1,2,3. As well as Amendment IX, paragraph 1.

3 Ibid, Amendment VIII, paragraph 4.

4 Ibid, Amendment IV, paragraph 1.

5lbid.
} 
equality and perhaps the most difficult provision for adopting a resolution in the Assembly of the Republic of Macedonia condemning genocide against the Albanian people in Macedonia in the period of 1912-1956.

Also, in point 3 of the platform were included legally completed criminal proceedings, several attacks and murders, which are required to be re-examined such as "Sopot", "Brodec", "Monster" and "Kumanovo" through an inquiry committee or an international independent body.

A few months later, President Ivanov will say that the goal of the platform of the Albanian parties is not for unification of Macedonia but for Macedonia to be the next phase in the creation of a third Albanian state. Regarding the platform, he said that its intent is to equal the Albanian language with the Macedonian and to change the constitutional amendment that comes from the Ohrid framework agreement with which ethnic communities in Macedonia receive their right depending on their percentage of $20 \%$. The essence of the platform is to change the constitutional order of the Republic of Macedonia. That means, to turn Macedonia from a multiethnic society and a unitarian state to become bi-ethnic (EWB Archives 2017).

After accepting the conditions from the Tirana platform by the political party SDSM led by Zoran Zaev, a coalition was made between him and the ethnic Albanian party headed by Ali Ahmeti, as well as several smaller Albanian parties, on May 31, 2017, the new government was elected in the Assembly of the Republic of Macedonia. Meanwhile, the Tirana Platform is being implemented. A new law on the use of languages was adopted, the defendants were released, in the criminal proceedings "Sopot" and "Monster", integrated border crossings with Kosovo and Albania were made, according to point 6 of the platform.

In order to support our thesis and previous analysis, while we were writing this article, we conducted two questionnaires, one intended for the majority of the population in the state - Macedonians and another for the largest ethnic minorityAlbanians. Each of these two ethnic groups has answered five different questions (see page 10 and 11). From the following results, everyone who will analysis them can see that there is a clear division in the Macedonian society. These two political "key-actors" have a different vision on the future of the Republic. Macedonians think that Albanians should not have more rights than those assigned with Ohrid Framework Agreement in 2001, they oppose the idea Albanian language to become a second official language in the whole territory. Furthermore, this ethnic group consider that Albanians have already got all the rights which represent an international standard in respecting the law. On the other hand, Albanians are not satisfied with the recently given rights by the state, they consider themselves as discriminated group and in order to have the rights as Macedonians which means to be equal, they claim that the Albanian language must be a second official language in the Republic. We were surprised when we saw the result of the last question where the Albanian ethnic group answered that the western parts of Macedonia should not be separated from the state and merged with Albania which is contrary to the result of the last question in questionnaire 1 where Macedonians answered that the final goal of the Albanian's requirements on their human rights will lead to succession of the western part of Macedonia and its merging with Albania.

\section{Results - Questionnaire 1}

(The following questions were intended to Macedonian ethnic group)

1.Do you consider that the Albanians in the Republic of Macedonia have all the rights that represent an international standard in respecting the law?

Yes $(97.3 \%)$

No $(2.7 \%)$

2.Do you think Albanians have more rights than Macedonians, especially when it comes to employment? Yes $(82.1 \%)$

No $(17.9 \%)$

3.Do you agree that Albanian language should be a second official language, which is contrary to the Constitution of the Republic of Macedonia?

Yes $(2.3 \%)$

No $(97.7 \%)$

4.Do you think the Albanians should have more rights than those already assigned to them with the Ohrid Framework Agreement in 2001?

Yes $(7.6 \%)$

No $(92.4 \%)$ 
5.Do you think that the final goal of the Albanian's requirements on their human rights will lead to succession of the western part of Macedonia and its merging with Albania?

Yes $(75.3 \%)$

$(24.7 \%)$

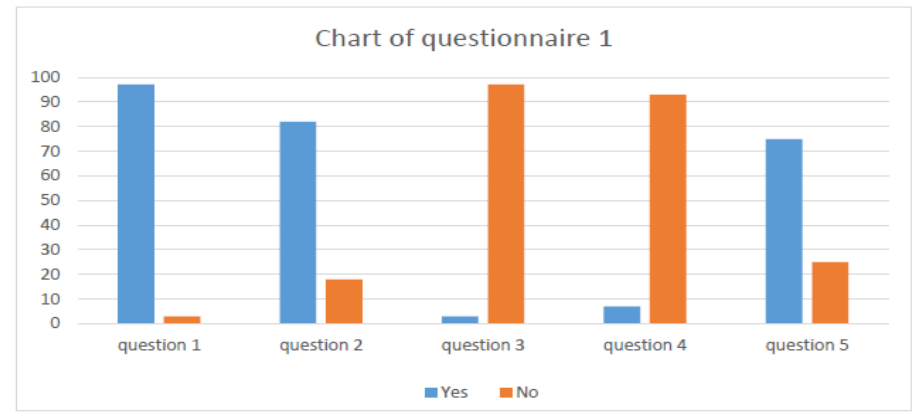

Results - Questionnaire 2

(The following questions were intended to Albanian ethnic group)

1.Are you satisfied with the rights which are given to you by the Republic of Macedonia?

Yes $(13.5 \%)$

No $(86.5 \%)$

2.Do you think you are on the same level (status) as the citizens of the Macedonian ethnic group?

Yes $(42.6 \%)$

№ $(57.4 \%)$

3.Do you think Albanians in the Republic of Macedonia should have more rights than those already assigned to them under the Ohrid Framework Agreement?

Yes $(95.1 \%)$

No $(4.9 \%)$

4.Do you agree that Albanian language should be a second official language in the Republic of Macedonia? Yes $(100 \%)$

No $(0 \%)$

5.Do you think that the western parts of the Republic of Macedonia (in the places where Albanians dominate) should be separated from the country and merged with the Republic of Albania?

Yes (6.5\%)

No $(93.5 \%)$

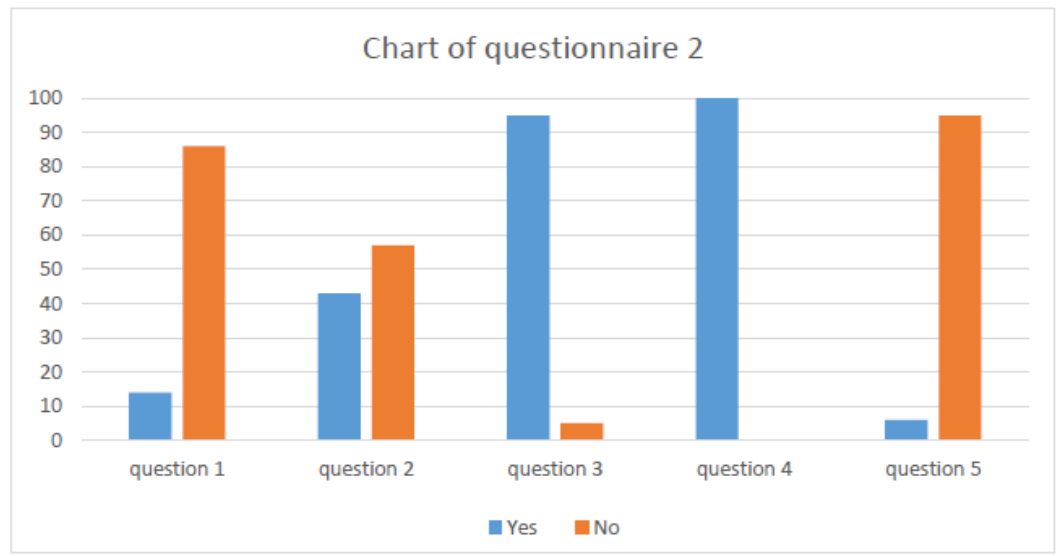




\section{Conclusion}

Multiculturalism is a serious issue, which always begins with minimal requirements of minorities, most often it turns into a conflict that causes, nationalism, hate speech and growing tensions, between the minority and the majority, and ends with a binational state or separation, depending on how strong is the state and its environment.

In the last, almost three decades, the political confrontation between Albanians and Macedonians has dealt with the longstanding desire of Albanians not to be recognized as a minority group equal with the majority, as equal partners in an institutional arrangement of the state.

This leads to a question of honesty or a hidden intent of these demands, as well as the loyalty of those citizens towards majority population and the whole state. That disloyalty towards one's own country, by establishing direct relations with another state, confirms that so-called rights demands lead to bi-nationality or separation from the home state. Moreover, this minority is no longer interested in the rights of other minorities in the state, but only its own.

Multiculturalism which proclaims differences as identities in which ignores the connection of resemblance leads to atomization, to a ghetto society. Multiculturalism does not permit an open society. In opposite, the extent to which multiculturalism nowadays is aggressive, secessionist intolerant, is the extent to which the given multiculturalism is the negation its self of pluralism.

The multicultural practices were not equally applied everywhere. The acceptance of multicultural practices depends on factors such as the desecration of ethnic relationship, human rights, border control, the diversity of the groups of immigrants, economic contributions. When those conditions are met, multiculturalism is seen as an unacceptable option.

In small or weak countries, there are different criteria for which rights should be given, and therefore, due to the lack of resistance by the state, it goes to the pointlessness of giving concessions. Due to the policy of the stronger, the interference of the neighboring states in its internal affairs, with the support of the international community on which they have a greater influence, not only provides more than it represents an international standard for minorities but also causes serious damage to the state, up to the limits of its abolition. Double standards are often applied.

\section{References}

[1] Reus-Smith, Christian. 2017. Cultural Diversity and International Order. International Organization, Cambridge University Press. Vol. 71, Issue 4. p.851-885.

[2] Fagan, Andrew. 2017. The challenge of cultural diversity: the limited value of the right of exit. Critical Review of International Social and Political Philosophy. Vol.21, Issue 1. p.87-108.

[3] Salat, Levente. 2001. Multiculturalismul liberal (Liberal multiculturalism), Lasi, Edit. Polirom.

[4] Wolf, Susan. 1994. The politics of recognition, in Guttman Amy, Examining the Politics of Recognition. New Jersey, Princeton University Press.

[5] Habermas, Jurgen. 1994. Struggles for recognition in democratic constitutional state, in Guttman Amy, Examining the Politics of Recognition. New Jersey, Princeton University Press. p.137.

[6] Kymlicka, Will and Cohen-Almagor R. 2000. Democracy and Multiculturalism, in R. Cohen-Almagor, Edit., Challenges to Democracy: Essays in Honor and Memory of Isaiah Berlin, London, Ashgate Publishing Ltd. p.89-90.

[7] Kymlicka, Will. 2012. Multiculturalism: Success, Failure, and the Future. Queen's University. p. 53-81.

[8] Sartori, Giovanni. 2007. Pluralism, Multiculturalism and Foreigners: An Essay on Multiethnic Society. Editura Humanitas. p.54.

[9] Rudomentof Victor. 2000. The Macedonian Question: Culture, Historiography, Politics, Columbia University Press.

[10] Todorova, Maria. 2009. Imagining the Balkans. Oxford University Press. p.269.

[11] Cvetkovski, Cvetan. Constitutional History of The Republic of Macedonia. Faculty of Law, Skopje. Internet: http://www.cecl.gr/RigasNetwork/databank/REPORTS/r1/Fyrom_R1_cvetkovski.html.

[12] Macedonian Academy of Sciences and Arts, Institute of National History ASNOM and the Macedonian State proceedings of the scientific meeting on the $70^{\text {th }}$ Anniversary of the First Assembly of ASNOM, held on NOVEMBER 28, 2014. Национална и универзитетска библиотека "Св. Климент Охридски", Скопје р. 10-11.

[13] Official Gazette of the Socialist Republic of Macedonia, Feb.25 1974 in Skopje, A Decision on the proclamation of the Constitution of Socialist Republic of Macedonia, no.03-487, paragraph 2. Original title:(Службен Весник на Социјалистичка Република Македонија, 25 февруари 1974 Скопје, Одлука за прогласување на Уставот на Социјалистичка Република Македонија, Број 03-487, став 2). 
[14] A Decision on proclamation of the Constitution of Republic of Macedonia, November 17, 1991 Macedonian Assembly, no. 08-4642/1, 17, in Skopje. Original title: (Одлука за прогласување на Уставот на Република Македонија, Број 08-4642/1, 17 ноември 1991 година на Собранието на Р.Македонија, С к о п ј е).

[15] International Crisis Group (ICG). 1998. The Albanian Question in Macedonia: Implications of the Kosovo Conflict for InterEthnic Relations in Macedonia. Internet: https://www.refworld.org/docid/3ae6a6d04.html.

[16] Jerker L. 2003. A Conflict Uppsala Analysis- Macedonia, Division for South- East Europe Uppsala University Printed by Edita Sverige AB, no.: SIDA3044en.

[17] Official Gazette of the Republic of Macedonia no.91, Macedonian Assembly on its session held on 16.11.2001 has adopted a Decision on proclamation of the amendments IV-XVIII of the Constitution. Also, Official Gazette of the Republic of Macedonia no.91, date: 20.11.2001, Amendment IV, V, VI, paragraph I.

[18] Official Gazette of the Republic of Macedonia no.91, date: 20.11.2001, Amendment VIII, paragraph 1,2,3. As well as Amendment IX, paragraph 1 and 4.

[19] European Western Balkans. 2017. Ivanov: Essence of Tirana platform is to change constitutional order. Internet: https://europeanwesternbalkans.com/2017/04/07/ivanov-essence-of-tirana-platform-is-to-change-constitutional-order/. 